PEDAGOGISK FORSKNING I SVERIGE Vol 26 No 2-3 (2021) ISSN 1401-6788

\title{
Pedagogisk forskning i Sverige - 25 år i kunskapsbildningens tjänst
}

Daniel Sundberg

Linnéuniversitetet

\section{ETT UPPDRAG SOM FÖRPLIKTIGAR}

Pedagogisk forskning $i$ Sverige har 2021 funnits i 25 år. Det är något vi särskilt vill uppmärksamma i detta jubileumsnummer. I denna inledning vill vi som nuvarande redaktion göra några reflektioner kring tidskriften, dess uppdrag och de utmaningar som vi kan se framgent.

Pedagogisk forskning $i$ Sverige har under sina år etablerat sig som en central arena för de pedagogiska samtalen mellan forskare, professionella yrkesutövare, beslutsfattare och politiker och andra intresserade av utbildning, skola, lärande och utveckling. När vi idag summerar statistiken kring tidskriften kan vi konstatera att enbart under de två senaste åren så har bortåt 200 forskare och författare ett aktivt konto i tidskriften och statistiken säger att texterna bara det senaste året (augusti, 2020 - augusti, 2021) totalt sett har mer än 120000 nedladdningar. Tidskriften finns i ett nätverk och en infrastruktur av forskare inom det pedagogiska kunskapsområdet. Totalt har till exempel 287 granskare vid mer än 25 olika svenska lärosäten tillfrågats och/eller registrerat sig hos Pedagogisk forskning $i$ Sverige sedan 2018.

Tidskriftens programförklaring lyder "att med hög vetenskaplig kvalitet bidra med analyser av pedagogik $\mathrm{i}$ vid mening och att låta olika inriktningar, traditioner och perspektiv prägla innehållet. Tidskriften är ett självständigt och oberoende forum för pedagogisk utveckling baserat på nya forskningsresultat, tematiseringar av den offentliga utbildningsdebatten och 
genom samlandet av forskare, beslutsfattare och yrkesverksamma i dialog och kunskapsutbyte”. Det är ett uppdrag som förpliktigar, inte minst i en tid som präglas av anglisering, tillämpning, specialisering och en högt uppskruvad publiceringstakt.

Tidskriften startade 1996 med sitt nuvarande namn, men historiken går egentligen tillbaka till den första professorn i pedagogik i Sverige, Bertil Hammer (1877-1929). Han var ansvarig utgivare för Svenskt Arkiv for Pedagogik under perioden 1912-1929 (Härnqvist, 2001). Det pedagogiska kunskapsområdet har under sin 110-åriga ämneshistoria sedan Hammers professorsinstallation genomgått stora förändringar (Forsberg \& Sundberg, 2018). Idag är det pedagogiska kunskapsområdet ett av de största vetenskapsområdena inom den högre utbildningen sett till antalet studerande, och forskningen är väletablerad vid så gott som varje svenskt lärosäte. Kunskapsområdet har rört sig i mångvetenskaplig riktning och utmärks idag av en hög grad av tvärvetenskap (t.ex. i samspel med psykologi, sociologi, historia, statsvetenskap etc.). Samtidigt som kunskapsområdet har breddats och specialiserats finns det få gemensamma forum i och med att också tidskrifter inom området blivit alltmer specialiserade (Nordvall \& Nylander, 2016).

Pedagogisk forskning $i$ Sverige har, menar vi, blivit alltmer angelägen som överbryggande forum över olika specialistområden för en kvalificerad forskningsbaserad kunskapsutveckling och för att motverka en fragmentisering. Som en av få mötesplatser och kommunikationsarenor för kvalificerad kunskapsutveckling på svenska bildar tidskriften ett nödvändigt komplement till en snabbt ökande andel specialiserade facktidskrifter med publicering på engelska (Lindblad m.fl., 2004). Ett högt uppskruvat publiceringstempo har också försvårat bildande samtal, initierad debatt och ett gemensamt ansvar för den innehållsliga infrastrukturen av samarbeten mellan och över olika specialområden, kompetenser och en gemensam kvalitetssäkring av områdets kunskapsbildning.

Redaktionen för Pedagogisk forskning i Sverige har sedan 2018 varit förlagd till Linnéuniversitetet som arbetat med att ta steg mot att skapa en digital openaccesstidskrift med ökad tillgänglighet och spridning till alla tidskriftens målgrupper, inte minst utanför universiteten. Tidskriften är idag en central nod $i$ infrastrukturen och kommunikationen inom det pedagogiska kunskapsområdet i Sverige men också alltmer mot professionella yrkesutövare och beslutsfattare. Denna övergång till att bli en digital open-acess-tidskrift sörjs förstås av alla oss som gärna handgripligen bläddrar i en tidskrift. Men samtidigt har övergången helt klart inneburit att innehållet har nått såväl fler läsare som nya målgrupper. Idag laddas en forskningsartikel ned nästan 500 gånger (medelvärde) redan de första två åren, med variation från 2600 till 60 nedladdningar (från 2018 och framåt). 
Vi i redaktionen avser, i enlighet med programförklaringen, fortsätta att med tidskriftens utgivning och verksamhet belysa, undersöka och diskutera problemställningar gällande utbildning, lärande och skola och dess olika institutioner, historiskt och i samtid. Uppdraget att ge perspektiv, väldokumenterade och skarpa analyser och resultat av olika pedagogiska frågor och förhållanden och deras konsekvenser för politik och praktik framstår fortsatt som en angelägenhet av rang.

\section{MOT KOMMANDE UTMANINGAR}

Så, hur ser framtiden ut för en tidskrift som Pedagogisk forskning i Sverige? Vilka utmaningar möter uppdraget de kommande 25 åren? En första utmaning rör hur olika kommunikationsarenor idag är sammankopplade. Samtidigt som forskningen inom ämnesområdet orienterar sig mot internationella publiceringsarenor och många forskare i första hand vänder sig utåt, har vi en differentiering nationellt och lokalt som medfört att många forskare (juniora såväl som seniora) har svårt att navigera ens vid det lokala lärosätet kring pedagogisk forskning utanför sitt eget specialistområde (Hasselgren, 2011; Lindblad m.fl., 2004).

Det pedagogiska kunskapsområdet är i sig interdisciplinärt och flervetenskapligt. Forskare från olika discipliner, till exempel psykologi, sociologi, filosofi, historia och statsvetenskap, bidrar till fältets utveckling. Inom kunskapsområdet pågår debatter om fältets epistemologiska status. Ska det förstås som en egen disciplin, en sub-disciplin eller ett helt öppet kunskapsområde för tillämpad forskning (Forsberg \& Sundberg, 2018)? Sedan 2000-talets första decennium har kunskapsområdet vidgats och behovet av samlade forum ökat. Detta blir särskilt tydligt i nummer 5, 2018, "Professorer inom det pedagogiska kunskapsområdet har ordet", där 16 ledande företrädare som håller på att lämna akademin för pension reflekterar över ämnesområdets utveckling vid 12 olika lärosäten. Författarna representerar flera olika inriktningar såsom exempelvis pedagogiskt arbete, didaktik, pedagogisk psykologi, utbildningssociologi, internationell pedagogik och specialpedagogik. Sammantaget utgör dessa olika inriktningar och perspektiv viktiga delar i en fördjupad förståelse för utbildning, lärande och skola.

Det finns alltså flera utmaningar för tidskriften kring att fortsatt försöka vara en central mötesplats för olika röster, ämnen, discipliner och perspektiv, inriktningar och skolbildningar. Med förskjutningen mot mer anglosaxiskt präglade publiceringsmönster även inom utbildningsvetenskaperna (Hansén \& Lindblad, 2010) blir forskningsresultat svårtillgängliga för svenska läsare utanför fackkretsarna. Vi menar att detta är en påtaglig risk för forskningen inom området, då kommunikationen mellan och över olika inriktningar och specialiseringar försvåras. Som redaktion ser vi det därför som en prioriterad 
uppgift att försöka vara ett forum för forskning publicerad på svenska som speglar utvecklingen inom olika delområden. Här blir det särskilt viktigt att attrahera forskare att publicera forskningsöversikter och synteser av den internationella och nationella forskningsfronten inom specialområden för en svensk läsekrets.

Sammanfattningsvis konstaterar vi att de första 25 år varit framgångsrika i att etablera ett centralt forum för kunskapsutveckling inom det pedagogiska kunskapsområdet. Vi ser att de kommande årens utmaningar inte minst handlar om att bredda kommunikationen i olika former och fördjupa analyser, samtal, möten som når pedagogiska forskare, beslutsfattare och pedagogiskt yrkesverksamma. Här utgör originalforskning, ofta av sådan karaktär att den inte är specialiserad, utan riktar sig till vidare läsekretsar, såväl som essäer som ger kritiska perspektiv på aktuella frågor inom utbildning och skola, recensioner av ny facklitteratur, debatt, fakultetsopponenters sammanfattningar, meddelanden om till exempel aktuella konferenser, forskarutbildningskurser och disputationer runt om i Sverige et cetera, viktiga angelägenheter.

I detta jubileumsnummer får vi ta del av senior professor Sverker Lindblads och professor emeritus Mats Ekholms perspektiv och reflektioner kring tidskriftens utveckling. De var med och startade tidskriften och ger i öppningstexten inblickar, motiv och diskussioner kring hur tidskriften och det akademiska landskap som den ingår i har förändrats och vilka utmaningar som detta idag aktualiserar. Härtill bidrar också två ytterligare notat från de pågående SWERA-samtalen; dels om kollegial bedömning inom akademin som Eva Forsberg (Uppsala universitet) och Sara Levander (Högskolan i Gävle) skrivit kring, dels om bedömning i forskarutbildningar utifrån samtal i SWERA:s doktorandråd, författad av Maria Rosén och Tina Lidström.

I tre artiklar kan vi ta del av aktuella forskningsteman inom det pedagogiska kunskapsområdet. De behandlar normkritik och normkritisk pedagogik (Helena Hill), nyanländas lärande i mottagandeplaner (Anna Ehrlin \& Ulrika Jepson Wigg) och meningsbegreppet i pedagogiken (Robert Ohlsson). I en essä tematiseras också vad undervisning $\mathrm{i}$ fritidshemmet kan vara (Jens Gardesten). I två olika debattinlägg ställs viktiga frågor för den framtida forskningen inom det pedagogiska kunskapsområdet, dels om praktiknära forskning (Glenn Hultman), dels om forskares autonomi i en tid av nyttighetskrav (Christer Fritzell).

Vi hoppas med detta att numret ska bli ytterligare bränsle i den pedagogiska kunskapsutvecklingens tjänst.

/Redaktionen genom Daniel Sundberg 


\section{REFERENSER}

Forsberg, Eva, \& Sundberg, Daniel (2018). Formeringen av det pedagogiska kunskapsområdet: Mot ett forskningsprogram. Pedagogisk Forskning i Sverige, 23(5), 5-19.

Hansen, Michael, \& Lindblad, Sverker (2010). Forskningskommunikation och publiceringsmönster inom utbildningsvetenskap: en studie av svensk utbildningsvetenskaplig forskning vid tre lärosäten. Vetenskapsrådet.

Hasselgren, Björn (2011). Tidskriften Pedagogisk Forskning i Sverige Forum för pedagogisk debatt? Redaktionell kommentar. Pedagogisk Forskning i Sverige, 16(4), 305-308.

Härnqvist, Kjell (2001). En granskning av tidskriften Pedagogisk Forskning i Sverige. Pedagogisk Forskning i Sverige, 1(2), 104-105.

Lindblad, Sverker, Kyndel, Dag, \& Larson, Lena (2004). Internationella arenor för utbildningsvetenskaper: om forskarorganisationer, vetenskapliga tidskrifter och överstatliga organisationer. Vetenskapsrådet.

Nylander, Eerik \& Nordvall, Henrik (2016). Kartläggning av tidskrifter inom det pedagogiska kunskapsområdet. SWERA-tidskriftsråd. 